\title{
7. АНАЛІТИКА
}

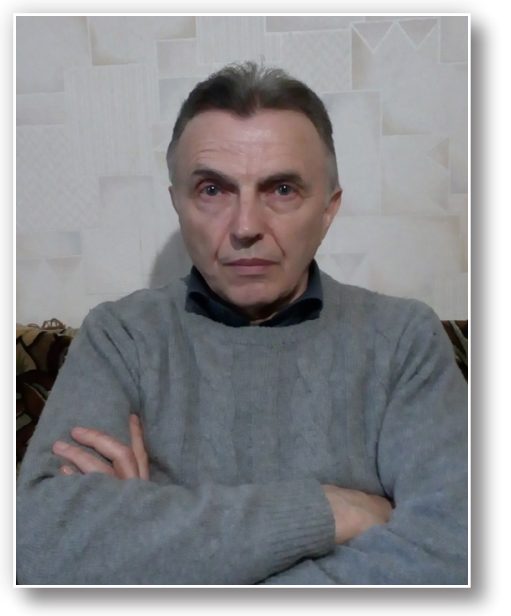

Іван Степанович Волощук, доктор педагогічних наук, завідувач відділу інноваційних технологій в освіті обдарованих Інституту обдарованої дитини НАПН України, м. Київ, Україна

ORCID: https://orcid.org/0000-0001-9300-0584

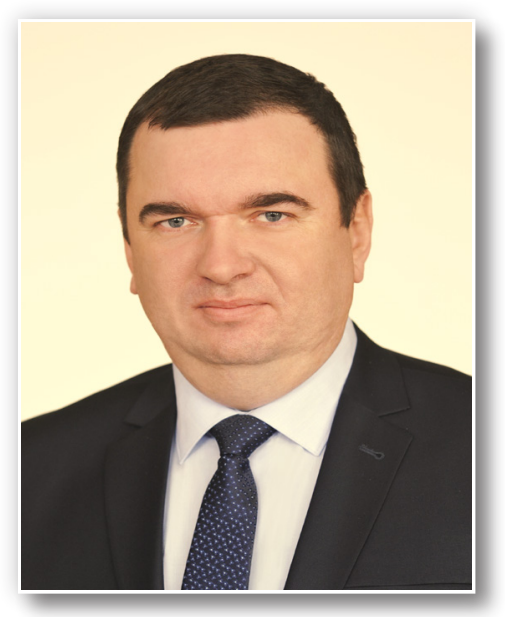

Ярослав Михайлович Рудик, кандидат педагогічних наук, доцент кафедри методики навчання та управління навчальними закладами Національного педагогічного університету імені М.П. Драгоманова, м. Київ, Україна

ORCID: https://orcid.org/0000-0001-5382-1505

УДК 376.54

DOI https://doi.org/10.32405/2309-3935-2020-3(78)-105-112

\section{КОНЦЕПЦІї ІНТЕЛЕКТУ: ПОСТУП ВПЕРЕД ЧИ РУХ ПО ЗАЧАРОВАНОМУ КОЛУ}

Анотація.

3 античних часів людство використовує поняття «інтелект» для того, щоб передати властиву індивіду властивість пізнання світу, пристосування до нього і часткової його зміни. Через два тисячоліття виявилося, щзо ми маємо задовільні знання, щзо стосуються суті інтелекту, можемо більш-менш успішно визначати рівень інтелекту індивідів у широкому діапазоні віку, не знаючи структуру изього складного феномена, фізіологічні процеси, щуо $\epsilon$ основою його прояву на рівні психіки. Причину потрібно шукати в складності об 'єкта дослідження. 3 іншого боку, зроблений ретроспективний аналіз досліджень суті інтелекту переконує нас в тому, щуо дослідники насамперед спрямовували свою увагу на красиві умоглядні побудови, а не на емпіричні факти, щзо проливають світло на суть інтелекту, його структуру, фізіологічні механізми процесів, залучених в інтелектуальній діяльності тощо. У статті показано, щзо ми маємо багато концепиій інтелекту та жодної адекватної його теорії.

Ключові слова: інтелект; концепція; теорія; розвиток; відмінність.

Неможливо точно вказати, хто з античних філософів першим використав слово, що в перекладі на українську мову означає «інтелект». Оскільки Арістотеля вважають батьком психології, то доречно розпочати історичний екскурс уявлень $\mathrm{i}$ знань про інтелект саме з нього.

Завдяки інтелекту, згідно з Арістотелем, здобуваються знання. Завдяки інтелекту людина пізнає світ, пристосовується та змінює його. У контексті пізнавальної діяльності людини філософ не обходить увагою п'ять органів відчуття, за допомогою яких людина отримує первинну інформацію про об'єкти та явища оточуючого ії світу. Центральним конструктом інтелекту Арістотель вважав мислення, перебіг якого потребує використання уявних образів. Проте, на його думку, коли деякі тварини можуть уявляти, лише людина може мислити. I мислить вона не лише конкретними, а й абстрактними образами.

Зазначений філософ, увівши у науковий обіг термін «інтелект», не дав відповіді на питання, чим постає інтелект із психологічної точки зору. 
Упродовж двох тисячоліть психологи намагалися дати вичерпне, придатне 3 теоретичної і практичної точок зору, визначення інтелекту. Не вдаючись до повного їх переліку (що практично не можливо), не переслідуючи ідею навести найбільш вдале визначення чи декілька таких, цінних посвоєму, необхідно зазначити, що під інтелектом, як один із варіантів, розуміють інтегральний прояв здібностей, знань та вмінь особистості. Згідно 3 В. Шадріковим, інтелект визначається рівнем розвитку здібностей, обсягом наявних знань, умінням їх використовувати в різних життєвих ситуаціях, зв'язком, тобто цілісним характером функціонування особистості.

Аналіз засвідчує, що визначення інтелекту фокусуються переважно на здібності до засвоєння і використання людського досвіду. Частково інтелект можна уявити як репертуар знань і способів діяльності. Відмінності, що проявляються між особистостями в обсязі (кількості) і якості (своєрідності) цього репертуару, є відмінностями в інтелекті. Інтелектуальні ж здібності, як вважають Е. Мілгрем та Лі Гонг, є реальними чи потенційними можливостями особистості засвоювати i використовувати ці знання.

Інтелект - це здібності до здобування i використання знань (у широкому розумінні людського досвіду). Про інтелект судять на основі його знань, умінь їх застосувати та швидкості опанування знаннями та вміннями. Іншими словами, здібності до засвоєння знань та вмінь і,тим паче до швидкого їх засвоювання впродовж тривалого відрізка часу вчені розглядають як основи людського інтелекту. Навіть така авангардна концепція інтелекту як концепція множинних інтелектів Г. Гарднера [1] визнає пізнавальні та репродуктивні здібності в ролі основи інтелекту. Але якщо попросити учнів будь-якого класу чи школи назвати найдотепнішого серед них, то за лічені секунди отримаємо набір відповідей, що переважно будуть збігатися. Такий консенсус частково обумовлено тим фактом, що винахідливість (творчі здібності) належить до набору домінантних атрибутів інтелекту.

На думку Р. Стернберга і П. Григоренко, інтелектуальні здібності - це сукупність властивостей, що наявні в основі засвоєння та використання знань. Їх можна розподілити на: аналітичні, синтетичні та практично-контекстуальні.

Разом $з$ тим, на зорі вивчення інтелекту було здійснено спроби ототожнити його з будь-якою однією здібністю. Автори зазначених спроб насправді не зводили інтелект до однієї здібності, а лише виділяли їі як домінантну. Важко повірити, наприклад, що Ф. Еббінгаус ототожнював інтелект виключно зі здібністю комбінувати, з'єднувати попередньо розрізнені елементи знань. Важко повірити, що основою інтелекту людини є iї здібність пов'язувати з окремими елементами арсенал наявного життєвого досвіду, що одним із проявів, як у Гельброннера має відтворення предмета за його контуром. Певною мірою можна погодитися з С. Райсом, який визначає основою інтелекту логічне мислення особистості. Цілком природно було б помістити основою інтелекту здібність розв'язувати задачі. Так, Е. Дружинін доречно зазначає, що інтелект як загальна здібність розв'язувати задачі був першим предметом дослідження фахівців у галузі психології індивідуальних відмінностей.

3 огляду на методологічні обмеження, спричинені хронологічними рамками, у яких виконувалися дослідження, А. Біне на початку своєї наукової кар'єри погоджувався $з$ позиціями М. Міля, який вважав, що інтелектуальну діяльність людини можна пояснити законами асоціанізму. Доречно зауважити, що згодом А. Біне збагнув обмеження цієї теорії, проте ідеї М. Міля продовжували позначатися на його роботі. Заслугою А. Біне є його внесок у розвиток концепції інтелекту, у якій на початку інтелект ототожнювався 3 концентрацією уваги. Згодом до досліджень долучився К. Сімон, що мало наслідком формулювання модернізованої концепції інтелекту. Зокрема, зазначені автори пов'язали інтелект зі здоровим глуздом, вважаючи, що в інтелекті є фундаментальна здібність, деформація чи відсутність якої $є$ важливою для практичного життя. Ця здібність є судженням, що іншими словами називають здоровим глуздом. Особистість за недостатнього розвитку здорового глузду може бути недоумкуватою або імбецилом. Зазначені автори суттєво розширюють множину компонентів інтелекту, вважаючи, що ця інтегрована якість охоплює пам'ять, моторні здібності, практичні навички, сенсорні відчуття, логічне розмежування даних попереднього досвіду, розмежування абстрактного, естетичне порівняння, логічне мислення, впорядкування, розуміння замислу художнього твору, критичне мислення, практичноморальні якості.

Так, К. Берт визначає інтелект як якість, що є інтелектуальною, а не емоційною чи моральною, а $з$ іншого боку інтелект є утворенням, притаманним усьому, про що людина думає, говорить чи робить. Проте обмеження в певній діяльності не $€$ доказом дефектності інтелекту. Врешті інтелект є вродженим утворенням, а отже, нестача інтелекту не доводиться відсутністю освіти. Науковець був активним прихильником спадкової природи рівня інтелекту, використовуючи для відстоювання власних поглядів (інколи були суперечливими) часом шахрайські дані. Однак він не вважав, що рівень інтелекту на 100 \% визначається спадковістю. Проте, К. Берт вважає, якщо на рівень інтелекту впливає фактор оточуючого середовища, то він також має генетичні причини.

На думку К. Берта, інтелектуальний розвиток фіксується в 11 років, що слугувало причиною 
пропонування ним Eleven-Plus іспиту, за результатами якого учнів ділили на два потоки: одні продовжували навчатися в граматичній школі 3 виходом на університети, а інші - у звичайній школі без будь-яких шансів на університетське навчання.

Після праць А. Біне, К. Сімона і К. Берта стало зрозуміло, що представити інтелект однією здібністю не видається можливим. Проте таке визнання породило інше принципово важливе питання. Воно також стосується структури інтелекту. Аналізуючи результати тривалої дискусії щодо структури інтелекту, можна дійти висновку, що епіцентром дискусії було (і залишається актуальним) питання, чи можна в інтелекті людини виокремити набір компонентів, що $є$ основою будь-якої інтелектуальної діяльності. Узагальнюючи результати зазначеної дискусії, можна виокремити два діаметральні підходи, перший 3 яких отримав назву унітарної моделі структури інтелекту.

Трактування інтелекту як унітарної сутності (на основі поділу його структурних складових на загальні і спеціальні здібності) є найвпливовішою концепцією з часів Ч. Спірмена. Сьогодні окремі автори визнають, що концепція, яка передбачає поділ інтелекту на загальний (g) і спеціальний (s), може бути шкідливою в освітніх колах. Проте будь-хто, хто вважає, що унітарна структура інтелекту вже вийшла зі використання, має взяти до уваги пристрасті, які вчинилися у зв'язку з опублікуванням книги «The Bell Curve». Ця праця, у якій натхненно захищають концепцію інтелекту, як унітарного утворення, породила значну кількість дебатів в освітньому середовищі. I хоча більшість педагогів не погоджуються 3 авторськими рекомендаціями соціального характеру, проте цілком розділяють наукову позицію авторів наведеної праці. Проте дослідник I. Йенсен зайшов так далеко, що вважає Triarchic Theory P.Стернберга схожою з ідеєю Ч. Спірмена.

Так, I. Йенсен запропонував робоче визначення інтелекту як g-фактора невизначено значної та різноманітної батареї розумових завдань. На його думку, ми доходимо висновку про те, що $g$ відіграє винятково важливу роль у реальному житті на основі того, що $g$ містить найбільш важливий компонент серед тотальної різноманітності в стандартних тестах інтелекту, i, що те саме $g \in$ найбільш важливим компонентом серед їх кількості в освітніх досягненнях. Причому він використав ідею Ч. Спірмена про загальний фактор інтелекту, а в його теорії інтелект ділиться на два різні набори здібностей:

1) здібності першого рівня пояснюють функціонування пам'яті і простого асоціативного навчання;

2) здібності другого рівня охоплюють абстрактне мислення і концептуальну думку.
3 наведеного аналізу випливає висновок про неможливість звести інтелект до однієї здібності. Тести, що зорієнтовані на діагностику однієї здібності, довели неможливість виокремити таке явище, що у своєму зовнішньому прояві виключно та повно характеризувало б інтелект. 3 іншого боку, не користується популярністю концепція, згідно 3 якою інтелект $є$ сукупність здібностей, серед яких можна виокремити загальні (притаманні всім видам інтелектуальної діяльності) та спеціальні (властиві окремим видам інтелектуальної діяльності).

Унітарну концепцію час від часу піддають критиці. Свого часу Ч. Спірмен з'ясував, що до структури загального інтелекту в ролі складників належать лінгвістичний (вербальний), механічний (просторово-динамічний) і математичний інтелекти. Необхідно зазначити, як вказує Е. Дружинін, що практично всі дослідники погоджуються щодо трьох основних складників загального інтелекту: числовий, просторовий, вербальний.

Діаметрально протилежною до унітарної моделі структури інтелекту є концепція множинних інтелекті в Г. Гарднера, що фактично заперечує наявність загального та спеціального інтелекту. Учений відстоює позицію, що в інтелекті можна виокремити декілька незалежних сфер, відповідно до типів інтелектуальної діяльності. Спочатку автор виокремив сім типів інтелекту, а згодом доповнив зазначену множину восьмим типом. Так, Г. Гарднер, вказуючи на зручність унітарного підходу до трактування інтелекту у процесі ранжування особистостей за рівнем розвитку, вказував на непридатність такого підходу до виявлення сильних і слабких сторін їхнього інтелектуального розвитку. Він запропонував модель, згідно 3 якою інтелект людини репрезентується такими складниками: лінгвістична, логічноматематична, просторова, музична, тілеснорухова, внутріперсональна, міжперсональна, натуралістична.

Автор визначає унікальність когнітивної структури особистості комбінацією перелічених складників. Необхідно зазначити, що спочатку концепція Г. Гарднера знайшла прихильників у середовищі ліберально налаштованих учених. Ця концепція дістала поширення в освітньому просторі, оскільки спроможна розрядити наелектризоване суспільство, виставляючи гасло, згідно 3 яким практично усі психічно здорові особистості спроможні до ефективної інтелектуальної діяльності, лише кожний у власній сфері залежно від притаманного йому типу інтелекту. Однак згодом популярність концепції Г. Гарднера в освітніх колах почала зменшуватися. У наукових колах вона розглядається як одна 3 можливих.

Перелічені вісім сфер інтелектуальної діяльності (вісім типів інтелекту) Г. Гарднер розглядав 
не ізольовано, а вказував на їх взаємозв'язок. Зокрема, особистість 3 високим рівнем формальнологічного інтелекту ймовірно буде володіти високим рівнем просторового та вербального інтелекту. Особистість з високим рівнем просторового інтелекту ймовірно буде володіти високим рівнем вербального інтелекту, але нічого конкретного про його формально-логічний інтелект сказати не можна. Особистість, яка володіє високим рівнем вербального інтелекту, може володіти високим або низьким рівнем просторового чи формальнологічного інтелекту.

Очевидно, що не всі люди володіють тим чи іншим культурним (інтелектуальним) кодом. Як наслідок, у частини дітей виникають проблеми 3 опануванням мови, 3 просторовим мисленням, лічбою тощо. Окрім того, дітей з високо розвиненим вербальним інтелектом більше, ніж 3 просторовим, а $з$ просторовим більше, ніж з формальнологічним. Чому це так? Відповідь на це питання поки що відсутня. Однак є відповідь, як зазначає Е. Дружинін, на таке питання: «Чому особистість з високо розвиненим формально-логічним інтелектом є цінністю для суспільства?»

3 ідеєю Г. Гарднера про множину інтелектів співзвучні результати дослідження Ф. Тейлора, лише 3 тією різницею, що останній зосереджує увагу на множині талантів. Використовуючи результати дослідження Л. Терстоуна стосовно векторів розуму (Vectors of Mind), який виокремив десять структурних складників інтелекту, сім 3 яких назвали первинними розумовими здібностями (просторові, сприймання, обчислювальні, вербального розуміння, швидкості мови, пам'яті, логічного мислення). Так, Ф. Тейлор розробив підхід, побудований на ідеї множини творчих талантів (Multiple Creative Talent). Причому він виокремлює дев'ять галузей таланту: 1) академічний, 2) продуктивного мислення, 3) планування, 4) комунікації, 5) пророкування, 6) прийняття рішення, 7) застосування, 8) людських стосунків, 9) можливості розрізнення. Автор констатував, що обдаровані особистості, оцінені в галузі однієі діяльності як талановиті, можуть не бути талановитими в іншій.

Сьогодні розглядаються дослідження, пов'язані з пошуком єдиної здібності, яку можна помістити в основу інтелекту, а також структурні концепції інтелекту, що фактично означало відмову від ідеї представлення інтелекту однією здібністю. Окремою сторінкою в дослідженнях інтелекту є праці, які присвячені змістовому наповненню інтелекту, тобто пошуку здібностей, що в єдності репрезентують інтелект. Серед помітних результатів такого роду, запропонованих до 1980 р., варто назвати модель Structure of Intellect Дж. Гілфорда та концепцію Fluid and Crystallized Intelligences Р. Кеттела [2].

Модель інтелекту Дж. Гілфорда враховує розумові операції (пізнання, конвергентну продук- тивність, дивергентну продуктивність, оцінку, пам'ять), зміст інтелектуальної діяльності (конкретний, символьний, семантичний, поведінковий) і кінцевий продукт (одиниці об'єктів, класи об'єктів, співвідношення, системи, трансформацію, імплікацію). Згідно з Р. Кеттелом, інтелект можна представити у вигляді поточного та кристалізованого інтелектів. Перший характеризує те, з чим народжується індивід, другий - те, що він здобуває в процесі набуття життєвого досвіду.

У 1985 р. Р. Стернберг запропонував концепцію Triarchic Theory of Intelligence. На його думку, інтелект не $є$ унітарним утворенням, швидше існує декілька типів інтелекту, а тому прості визначення не можуть бути використані для того, щоб пояснити це складне утворення. Плутанина стосовно суті інтелекту сприяла розробленню Р. Стернбергом та іншими авторами моделей, які пояснювали б складну інтелектуальну діяльність. Трикомпонентна модель Р. Стернберга розглядає інтелектуальну діяльність у трьох вимірах: 1) завдяки першому типу інтелектуальної діяльності особистості пов'язує себе із зовнішнім світом; 2) завдяки другому типу налагоджує зв'язок зовнішнього середовища 3 власним внутрішнім світом; 3) завдяки третьому типу особистість отримує зв'язок із внутрішнім світом.

Плакер констатує, що концепції Дж. Гілфорда, P. Кеттела і Р. Стернберга є досить популярними серед психологів, проте не знаходять значної кількості прихильників серед педагогів. Потрібно зазначити, що названі концепції спочатку не були популярністю через складність, проте останніми роками вони завойовують дедалі більше прихильників в освітньому світі.

Щоб зробити науково більш адекватною i практично більш придатною, концепцію Р. Стернберга було модифіковано у 1990 р. Сесі, а у 1993 р. - Л.Керроллом. Однак ці модифікації не отримали належної уваги з боку практиків.

Однією з причин можна назвати той факт, що перелічені концепції суттєво обмежені в конструюванні валідних і надійних методів обстеження інтелекту, прогнозуванні на основі отриманих емпіричних даних діагностики інтелектуальних здобутків у реальному житті. Це не могло не спонукати дослідників до перегляду раніше запропонованих концепцій. У зв'язку зі сказаним не можемо не згадати таке прагнення модифікації попередніх ідей, як концепцію успішного інтелекту Р. Стернберга та П. Григоренко.

Серед сучасних концепцій інтелекту визначальне місце займають PASS-теорія [3], концепції емоційного та практичного інтелектів. Дати їм об'єктивне оцінювання сьогодні важко, тому що неможливо належним чином оцінити концепції Г. Гарднера і Р. Стернберга у 1983 i 1995 роках.

PASS-теорія (Planning, Attention, Simultaneous, Successive) виникла на основі досліджень вищих 
ментальних процесів і спричиненій ними когнітивній революції. Зазначена революція вплинула на концептуалізацію й обстеження інтелекту. PASS-теорія - це когнітивно-процесуальний підхід до здібностей, що грунтується на нейропсихологічних, когнітивно-психологічних та дослідженнях інформаційних процесів О. Лурії, який описав головні структурні блоки інтелекту як функціональні одиниці і вказав на існування базових когнітивних процесів, що слугують запорукою того, як певні здібності залучаються до відповідної діяльності. У зазначеній теорії вважається, що конструкти планування, концентрації, цільно-частковості та послідовності є базовими блоками когнітивного функціонування людини.

Планування - це психічний процес, завдяки якому індивід знаходить, відбирає, застосовує й оцінює розв'язки проблем. Він планує, оцінює цінність методу, відстежує його ефективність, перевіряє і відхиляє (у разі доцільності) старий план і розглядає його в ролі завдання, що потребує змін.

Концуентрація - це психічний процес, завдяки якому особистість вибірково зосереджується на окремих стимулах, подавляючи відповіді на сторонні стимули. Будь-яка інтелектуальна діяльність вимагає сконцентрованої, вибіркової, неперервної та наповненої зусиллями дії. Сфокусована увага передбачає концентрацію на діяльності, тоді як вибіркова увага вимагає стримування відповідей на відволікаючі стимули. Неперервність уваги пов'язана з різними зусиллями, що необхідні для розв’язання задачі.

Одночасне оперування цілим і його частинами $є$ запорукою того, що особистість інтегрує окремі стимули в єдине ціле. Цільно-частковість яскраво виражається як у вербальному, так і не вербальному контексті. Завдяки цьому процесу окремі слова інтегруються в єдине ціле - ідею. Особистості з розвиненою здатністю поєднувати окреме в ціле спроможні координувати різні факти та ідеї одночасно, щоб зрозуміти загальну картину.

Послідовне опрацювання - це психічний процес, завдяки якому особистість інтегрує стимули в специфічний серіал для того, щоб утворити ланцюгово-подібну послідовність. Яскравим прикладом цього є завдання на округлення чисел, зокрема, 0,386 до сотих. Щоб виконати це завдання потрібно знайти в ньому соті, потім подивитися на розряд, що знаходиться справа. Зафіксувати його, пригадати правила округлення і застосувати їх у конкретному випадку, отримавши 0,39. Особистості 3 добре розвиненим послідовним опрацюванням спроможні використовувати лінійний порядок подій для того, щоб розв'язувати проблеми, аналогічні до описаної.

Концепція емоційного інтелекту (Ю. Мейєр, Д. Карузо та ін.) набула на сучасному етапі неабиякого поширення. Вона покликана пояснити емоційну сферу індивіда, його емоційну реакцію та розуміння емоцій інших.

Концепція практичного інтелекту (Р. Стернберг) постає реакцією на той факт, що здібність до академічного засвоєння знань не є єдиним проявом інтелекту. У повсякденному житті ми неодноразово зустрічаємося 3 випадками, коли особистості, не будучи блискучими в академічній сфері, демонструють власний інтелект у практичному плані.

Аналіз засвідчує, що попередні та сучасні концепції інтелекту базувалися та базуються на накопичених знаннях, суті окремих аспектів інтелекту та механізмів інтелектуальної діяльності. Отже, на часі створення теорії інтелекту, що об'єднала б усі без винятку сфери інтелектуальної діяльності особистості. Такої теорії поки не існує, свідченням чого є поява теорії прихованого інтелекту (К. Дуек, Ч. Чіу, Н. Хонг та ін.).

У дослідженні інтелекту, окрім 3'ясування його суті, актуальною є проблема його розвитку. У з'ясуванні цього питання дослідники діляться на дві групи: перші заперечують можливість розвитку інтелекту; другі стверджують, що інтелект піддається педагогічному та соціальному впливу.

Відповідь на поставлене питання має вагому практичну значущість для кожної пересічної особистості. Так, К. Дуек з колегами виявила два неявні розуміння особистостями власного інтелекту. Особистості, які сповідують статичну ідею, розглядають інтелект як незмінну притаманну їм внутрішню характеристику, а ті, хто сповідує динамічне розуміння, вважають, що їхні інтелектуальні здібності можуть бути підвищені спонтанно чи завдяки спрямованим зусиллям. Зазначені науковці емпірично продемонстрували, що особистості першої групи менш імовірно пробують розв'язувати завдання на рівні виклику і перебувають у зоні ризику академічної неуспішності.

У теоретичному контексті проблема незмінності чи розвитку інтелекту проєктується на площини успадкованих задатків і педагогічного фактора. Дослідженням впливу генетичного та педагогічного факторів на рівень інтелекту вчені займаються понад століття. Наводяться теоретичні міркування та емпіричні факти: в одних вказується на виняткову роль успадкованих задатків, а в інших - домінантна роль відводиться впливу виховного середовища. Дослідники ж третьої групи більш обережні. Вони не заперечують ні генетичний, ні педагогічний фактори, іноді, навіть, намагаючись встановити співвідношення вПливу кожного 3 них.

Першим, хто порушив це питання, був Ф. Гальтон. Серед багатьох висновків, які автор висловлює на основі емпіричних даних, знаходимо, що висока обдарованість лише в одиноких випадках народжується у випадковому шлюбі без вибору. 
Здебільшого вона передається завдяки відповідному підбору в невеликому колі кастових сімейств, професійних і станових колах. За результатами шлюбів 3 собі подібними обдарованість передається частіше, ніж в шлюбах 3 іншими одноплемінниками, головним чином у середовищі дворянства, у родинах науковців, чиновників, іменитих громадян і художніх ремісників. Переконливими, на думку автора, $є$ результати вивчення генеалогії видатних людей. Було простежено родинні зв'язки 3500 відомих американців. Тоді як ймовірність близьких родинних зв'язків для середнього американця становить 1 : 500, ймовірність родинності цих видатних людей між собою дорівнює 1 : 5, тобто в 100 разів більша. На підставі зазначеного можна дійти висновку про те, що сім’ї талантів, що продовжуються у декількох поколіннях, створюються переважно за сприятливих умов. Переважно погоджуючись 3 наведеним висновком, ідею виняткового впливу потрібно сприймати обережно. Відомо чимало самородків, вихідців із сімей з низьким інтелектуальним розвитком. 3 іншого боку, можна навести приклади виродження інтелектуальних династій. Врешті, важко відповісти на питання: «Що превалює в наявності інтелектуальних династій: генетичний фактор чи традиції сімейного виховання?»

Так, вплив генетичного фактора ніхто не стане заперечувати. Однак генетичний вплив є різним на різні типи (поки що використовуємо цей термін у традиційному розумінні!) інтелекту. Дані психогенетичних досліджень засвідчують, що відмінності у вербальному інтелекті успадковуються більше, ніж відмінності у невербальному інтелекті (Е. Дружинін).

Ніхто не стане заперечувати факт розвитку інтелекту, а також його інтенсивного розвитку в ранньому віці. У ранні роки стрімкий розвиток інтелекту відбувається в усіх дітей, роблячи вирішальний внесок дитячих років у його становлення. Рівень інтелекту в дорослому віці пов'язано 3 надзвичайними можливостями ранніх років життя індивіда.

С підстави констатувати статеві інтелектуальні відмінності в рівні інтелекту осіб одного віку. Так, Дж. Бенбоу і У. Стенлі припускають, що статеві відмінності в математичному мисленні можуть мати біологічне походження, а інтелектуальні відмінності між чоловіками та жінками в математиці лише підсилюються впливами оточуючого середовища, такими, як вивчення різних навчальних предметів. Результати, отримані із залученням майже 10000 обдарованих дітей середнього віку, до тривалого дослідження Study of Mathematically Precocious Youth (SMPY), продемонстрували, що статева різниця в здібностях математично мислити значуща, стабільна й така, що з'являється в ранньому віці. 3 часом дані, отримані за результатами
Академічні досягнення з усіх навчальних дисциплін пов'язані 3 інтелектом. Тому з'ясування суті інтелекту, розроблення його теорії, придатної з наукової та практичної точок зору, має значущість для організації ефективного навчання учнів.

Розроблення адекватної теорії інтелекту важливе ще й тому, що на їі основі розробляють методики обстеження рівня інтелекту особистості, що насамкінець використовують в інтелектуальному ранжуванні учнів, організації їхнього навчання, що відповідає їхнім здібностям і запитам.

Адекватна теорія інтелекту та розроблені на іiі основі валідні і надійні методики його обстеження знаходить практичне застосування у професійній сфері. Важливо знати нижній поріг інтелекту в контексті досягнень у різних професіях. Так, Дж. Перкінс і Т. Гротзер вважають, що для кожної професії існує свій нижній поріг інтелекту. Особистості 3 інтелектом, нижчим порогового рівня для певної професії, не здатні їі опанувати. Якщо рівень інтелекту перевищує порогову значущість, то між рівнями досягнень і інтелекту неможливо відстежити зв'язок (Е. Дружинін). Результати тестування інтелекту корелюють 3 успішністю діяльності для різних професій у діапазоні від 0,10 до 0,85.

Наведені концепції інтелекту не вичерпують множину різних теоретичних підходів до 3'ясування його суті. Значна кількість концепцій і відмінність теоретичних засад, на яких вони побудовані, робить доцільною їх класифікацію. Так, P. Стернберг запропонував поділити наявні концепції інтелекту на географічні, обчислювальні, біологічні, епістемологічні, антропологічні та соціологічні, а Г. Гарднер, Д. Корнхабер і Уейк виділяють серед концепцій інтелекту психометричні, розвивальні, біологічні, когнітивні і сучасні. Натомість Г. Айзенк виокремлює біологічний, психометричний і соціальний інтелекти, фактично поміщаючи відомі йому моделі в названі три групи. Модель інтелекту - це його структура. Варто зазначити, оскільки структурувати інтелектуальну діяльність можливо по-різному, то і моделей інтелекту безліч. Проте найчастіше використовують моделі Р. Кеттела, Ч. Спірмена і Г. Гарднера.

Виникає проблема строкатості наведених вище класифікацій, а також певна невідповідність використовуваним системотвірним факторам. Однак потрібно зауважити, що наведені класифікації, як і проаналізовані вище концепції, лише підсилюють висновок щодо відсутності та необхідності адекватної теорії інтелекту.

Оцінюючи здобутки наукового пошуку в з'ясуванні суті інтелекту, можна апелювати до кількості досліджень, виконаних упродовж ХХ століття. Причому з наведеного вище доходимо висновку, що основна увага дослідників була «прикута» до виявлення однієї здібності - носія інтелекту, 
виокремлення сукупності здібностей, що притаманні усім видам інтелектуальної діяльності тощо. Виявились особливо важливими дослідження специфічних здібностей, що виходять за межі концепції загального інтелекту. Це породило появу різних типів інтелекту та труднощі, пов'язані з універсальним визначенням інтелекту.

До того ж, з часом у психології вкоренилася думка, що рівень інтелекту особистості та зафіксовані їі прояви в ситуації діагностики чи, навіть, в окремі моменти реального життя, речі далеко не тотожні.

Щоб обійти проблему, дослідники пропонують вести мову не про інтелект як такий, а лише про інтелектуальну поведінку. Причому стверджується, що атрибути інтелектуальної поведінки потрібно розглядати в контексті культурних i ситуативних факторів. Іншим компромісним підходом потрібно вважати введення в науковий обіг психометричного інтелекту - властивості, що обстежується за допомогою системи тестових завдань. У такому випадку йдеться не про інтелект, а лише про певну субстанцію, відомості про яку отримують шляхом використання певного інструментарію, що до моменту обстеження назвали тестом інтелекту. Зокрема Плакер доходить висновку, що попри кількість концепцій інтелекту та їх практичне застосування, багато 3 них досі не отримали належної перевірки й оцінювання.

Таким чином, констатуємо, що інтелект - це термін, що тривалий час використовується в теоpiї та на практиці. Достеменно відомо, що це не єдина психічна властивість, а їх сукупність. Охоплюючи психічні властивості терміном «інтелект», дослідники постають перед вибором: які 3 них охопити, а які залишити автономними поза інтегральним конструктом, який ми називаємо інтелектом. На різних етапах з'ясування суті інтелекту в його визначення неминуче вкладалися i будуть вкладатися різні значення до тих пір, поки не буде обгрунтовано аксіоматичну сутність цього феномена.

\section{Використані літературні джерела}

1. Gardner H. Frames of mind. New York : Teachers College Press, 1983. 528 p.

2. Cattell R.B. Structured personality-learning theory: A Wholistic Multivariate research approach. Centennial Psychology Series. New York : Praeger, 1983. 466 p.

3. Das J.P., Jarman R.P. Cognitive integration: Alternative model of intelligence / H.A.H. Rowe (Eds.). Intelligence: Reconceptualization and measurement. Hillsdale, NJ : Erlbaum, 1991. P. 163-182.

\section{References}

1. Gardner, H. (1983). Frames of mind. New York. 528 p.

2. Cattell, R.B. (1983). Structured personality-learning theory: A Wholistic Multivariate research approach. Centennial Psychology Series. New York. 466 p.
3. Das, J.P., Jarman, R.P., \& H.A.H. Rowe (Eds.). (1991). Cognitive integration: Alternative model of intelligence. Intelligence: Reconceptualization and measurement. Hillsdale, NJ: Erlbaum, P. 163-182.

Voloshchuk Ivan, Rudyk Yaroslav. Intellectual Concepts: Progress Forward or Moving on Charming Wheel.

Summary.

Since ancient times, humanity has used the concept of "intellect" in order to convey the inherent individual's property of knowledge of the world, adaptation to it and partial change it. Two millennia later, it has emerged that we have a satisfactory knowledge of the essence of intelligence, can more or less successfully determine the level of intelligence of individuals across a wide range of ages, without knowing the structure of this complex phenomenon, the physiological processes underlying its manifestation at the level of the psyche. First of all, the complexity of the object of study should be sought. On the other hand, a retrospective analysis of studies of the essence of intelligence convinces us that researchers primarily focused their attention on beautiful speculative constructs, rather than on empirical facts that shed light on the essence of intelligence, its structure, physiological mechanisms of processes involved in intellectual activity, etc. As a result, the article shows that we have many concepts of intelligence and no adequate theory of it.

In particular, Aristotle's contribution to the field of psychology in which intelligence is explored is emphasized. In addition, the results of studies of a whole galaxy of psychologists who have published their own vision of the essence of intelligence, intellectual differences between people in qualitative and quantitative dimensions are given. Comparison of their results made it possible to outline the trajectory of the movement of scientific thought in clarifying the essence of intelligence.

Initially, the intellect was sought to be associated with someone ability, most likely dominant. Subsequently, this idea was abandoned and several structural components were sought out in the intellect, attributing to them the status of principal. After that, they tried to prove that some structural components work in virtually all the kinds of intellectual activity. These kinds appeared to be so diverse and relatively remote that the idea of introducing the notion of type of intelligence into the scientific world arose. However, this idea did not overcome the idea of partial unitarity of intelligence in the form of separation of general and special intelligence. Consequently, concepts of successful, practical, emotional and other intellects were offered. But they did not cause any significant changes in clarifying the essence of intelligence.

$A$ certain breakthrough in the understanding of the essence of intelligence has emerged in connection with the cognitive revolution and the study of the neurophysiological mechanisms of intellectual activity. But scientific thought in this sense made only the first step. The horizons of an adequate theory of intelligence are only visible. 
Key words: intelligence; concept; theory; development; difference.

Волощук И.С., Рудик Я.М. Концепции интеллекта: продвижение вперед или движение по замкнутому кругу.

Аннотация.

С античных времен человечество использует понятие «интеллект» для того, чтобы передать присущее индивиду свойство познания мира, приспособления к нему и частичного его изменения. Спустя два тысячелетия оказалось, что мы имеем удовлетворительные знания, касаютиеся сущности интеллекта, можем более или менее успешно определять уровень интеллекта индивидов широкого диапазона возраста, не зная структуру этого сложного феномена, физиологические проиессы, лежащие в основе его проявления на уровне психики. Причину прежде всего следует искать в сложности объекта исследования. С другой стороны, проделанный ретроспективный анализ исследований сущности интеллекта убеждает нас в том, что исследователи в первую очередь начеливали свое внимание на красивые умозрительные построения, а не на эмпирические факты, проливающие свет на сущность интеллекта, его структуру, физиологические механизмы процессов, задействованных в интеллектуальной деятельности и т.п. В статье показано, что мы имеем много концепций интеллекта и ни единой адекватной его теории.

Ключевые слова: интеллект; кониепичи; теория; развитие; различие.

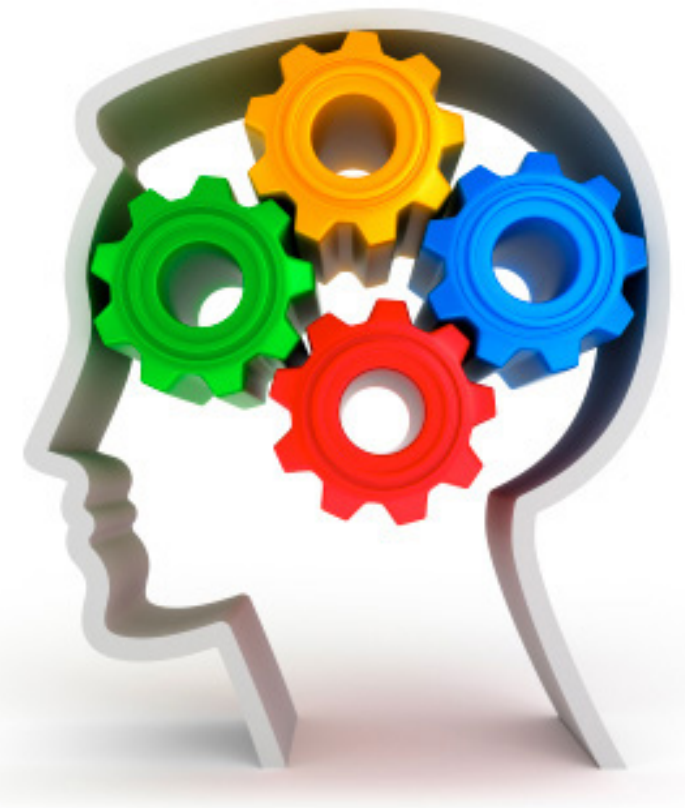

